\title{
Justification of necessity and analysis of state support of agro-industrial complex in the Russian Federation
}

\author{
Andrey A. Karavdin \\ Peoples' Friendship University of Russia (RUDN University) \\ 6 Miklukho-Maklaya St, Moscow, 117198, Russian Federation
}

\begin{abstract}
Issues related to state support of the agro-industrial complex are relevant for all countries of the world, including the Russian Federation. The article deals with the key problems of the agro-industrial complex, which are mainly caused by the features of agriculture. The necessity of state support for the agro-industrial complex of Russia on the basis of the identified problems is substantiated. The article analyzes the directions and measures of state support in Russia, the differences between the stated goals in the state program for the development of the agro-industrial complex and the results in practice. The lack of a comprehensive approach to solving existing problems and proper control over the implementation of the state program, ill-considered and insufficient funding of individual programs, lobbying by large agricultural holdings of their interests and the monopolization of agricultural production do not allow to rely on the development of small agribusiness and rural areas.
\end{abstract} subsidies

Keywords: agro-industrial complex, state support, agricultural policy, state program,

\section{Introduction}

The development of the agro-industrial complex and, as a result, the preservation of national and food security and independence is determined, among other things, by the level of state support, which is a key incentive for agricultural producers. In a broad sense, state support for agriculture is understood as assistance from the state to producers, processors and sellers of agricultural products, and in addition to raw materials and food.

The features given in the theoretical part of the article allow to understand how complex the agricultural sphere is. The agricultural sector is not able to be competitive in a market economy because of its specific characteristics. Compliance with the relationship between consumers and producers based on market principles should not exclude the active role of the state in regulating the interests of producers, consumers, and the entire agriculture economy. After all, only the state has the right, responsibilities and mechanisms of effective distribution of surplus value, created on the basis of the products of the primary producer. By providing economic support to primary producers, the state ensures the growth of food pro-

(C) Karavdin A.A., 2020

(i) This work is licensed under a Creative Commons Attribution 4.0 International License https://creativecommons.org/licenses/by/4.0/ 
duction and restrains the growth of prices in the consumer market. It is in this, and not only in the collection of taxes and expenditure of budget funds, the main role of the federal and regional authorities is reduced.

Therefore, one of the most significant factors of preservation, development and increase of efficiency of agricultural production is the state support, regulation and development of innovative activity.

\section{Literature review}

The problems of state support of the agro-industrial complex of Russia are widely covered in modern research literature. Among the numerous works on this subject, it is worth highlighting several works used in this article. In particular, the state support of agriculture was considered by A.A. Bukshpan, T.S. Gusak, O.S. Serdyuk (Bukshpan et al., 2018), A.A. Shutkov, S.A. Shutkov (Shutkov, 2016), I.G. Ushachev (Ushachev, 2016, 2017), N.I. Shagaida, V.Y. Uzun (Shagaida, Uzun, 2017; Uzun, 2019), L.A. Istomina (Istomina, 2013), A.A. Burmistrova, N.K. Rodionova, I.S. Kondrashova (Burmistrova et al., 2014), M.K. Kamilov, P.D. Kamilova (Kamilov, Kamilova, 2012), S.G. Privalova (2009).

\section{Methods}

In the article the author used different research methods, both theoretical and empirical: systematization, comparison, synthesis, generalization and analysis of various relevant sources of information and data that were taken from scientific research, statistical agencies and legal acts.

\section{Theoretical justification of the need for state support of agriculture}

As already noted, the support of the agro-industrial complex is aimed at solving the problems generated by the key features of the main sub-sector of the agroindustrial complex - agriculture, which distinguish it from other sectors of the national economy, and force the state to regulate and support the agro-industrial complex (Figure 1).

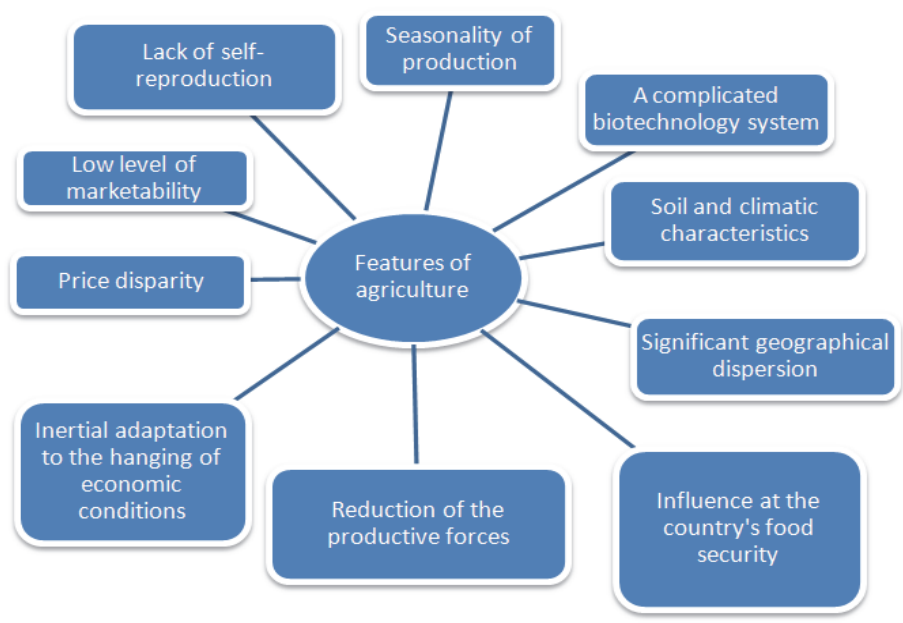

Figure 1. Features of agriculture

Source: compiled by the author (Karavdin, 2016). 
The features of agriculture are, for the most part, market flaws, which are aimed at eradicating the forces of the state. In Russia, there is still a lack of understanding that in economic terms agriculture is not a self-sufficient industry and the food market is not self-regulating (Privalova, 2009; Kamilov, Kamilova, 2012).

Of course, there is no sphere of human activity in which all the major flaws of the market are combined. But in the agro-industrial complex, the problems generated by the market economy are particularly acute. The main disadvantages (failures) of the market economic mechanism in the field of agriculture include:

- restriction of competition, the emergence and development of monopolies (in the conditions of monopoly the agricultural firm does not adapt to the prices spontaneously developing on the market, and chooses the most profitable combination of price and volume of output (sales), as a result, society as a whole suffers losses);

- the problem of public goods production (natural resources are public goods which, according to the social welfare theory, cannot be established by the market, in particular, due to the fact that individuals cannot be excluded from the consumption of public goods, and consequently, they may not be offered by the private sector, because they cannot get a fee; additionally, the consumption of these services does not require additional costs, that is, there is no competition in consumption);

- external or spillover effects are manifested in the form of adverse externalities (water and wind erosion, waterlogging, abandoned fields, forests, violation or noncompliance with land cultivation technologies and farming systems, etc.), which are associated with the development of the agricultural sector in a competitive environment; in particular, this flaw may be associated with the outflow of population from villages to cities, as well as the lack of a specific and clear state policy;

- the problem of asymmetric information arises due to the lack of sufficient and reliable information about the quality of products with large volumes of falsification and growing year-on-year imports of palm oil (for 2018 - more than a million tons); this market failure would be eliminated by the state by establishing various GOST standards, technical specifications, etc., with mandatory and not voluntary, as now, the implementation of these standards;

- incomplete markets (a striking example is agricultural insurance, which itself contains many flaws);

- macroeconomic instability (this flaw is one of the most important, especially in a crisis that has a very negative impact on the country's agro-industrial complex; the need for state intervention in this market failure is due to smoothing of the consequences of crises, supporting the population in rural areas, creating preferential conditions for loans, taxes, etc.);

- inequality in the distribution of resources and income (there is an inequality in the private and public discount rate in agriculture - the rate of profit earned from the production and consumption of natural resources).

\section{State support of the agro-industrial complex of Russia}

State support of the agro-industrial complex is provided within the framework of the State Program for the Development of Agriculture and Regulation of Agricultural Products Markets, Raw Materials and Food for 2013-2020 in the form of subsidies from the federal budget to the budgets of the subjects of the Russian Federation in the areas presented in Table 1. 


\section{Direction of support from the federal budget}

\begin{tabular}{ll}
$\begin{array}{l}\text { Development of } \\
\text { agribusiness } \\
\text { industries: }\end{array}$ & $\begin{array}{l}\text { - providing unrelated support to agricultural producers (green-box support for far- } \\
\text { mers) in the field of crop production; } \\
\text { - increase of productivity in dairy cattle breeding; } \\
\text { - assistance in achieving the targets of regional agricultural development programs } \\
\text { ("Single subsidy") }\end{array}$ \\
\hline $\begin{array}{l}\text { Stimulation of } \\
\text { investment activity } \\
\text { in agriculture: }\end{array}$ & $\begin{array}{l}\text { - support for investment lending in agriculture; } \\
\text { - seimbursement of direct costs incurred for the creation and(or) modernization of } \\
\text { agricultural facilities }\end{array}$
\end{tabular}

Technical and - subsidies to agricultural machinery manufacturers technological modernization, innovative development:

\section{Development of} reclamation of agricultural lands of the Russian Federation:
- subsidies for the implementation of activities of the direction "Development of reclamation of agricultural land in Russia"
Sustainable rural development:

\author{
- subsidies to improve the living conditions of citizens; \\ - subsidies for complex arrangement by objects of social and engineering infrastruc- \\ ture (water supply and(or) gasification); \\ - subsidies for the development of a network of the general education organizations; \\ - subsidies for the development of a network of medical assistants and obstetric points \\ and(or) offices of general practitioners; \\ - subsidies for the development of a network of plane sports constructions; \\ - subsidies for the implementation of projects of complex arrangement of platforms \\ under compact housing development; \\ - subsidies for grant support of local initiatives of citizens
}

Creation of a system to support farmers and development of rural cooperation

Source: Information guide on measures and directions of state support of the agroindustrial complex of the Russian Federation. Retrieved February 25, 2020, from http://www.gp.specagro.ru

This program was introduced in order to solve two fundamental problems of agricultural development: the possibility of increasing the profitability of agricultural producers and providing the country with its own food (Burmistrova et al., 2014).

The priority national project "Development of Agriculture" appeared in 2006. In the same year, the Federal Law "About the Development of Agriculture" was adopted (Federal Law.., 2006), which laid the foundations for a new state policy of support in the framework of state programs designed for the medium term. In 2013-2025, the second state program for the development of agriculture and regulation of markets for agricultural products, raw materials and food is being implemented (Shagaida, Uzun, 2017).

State support is provided through measures such as:

- preferential tariff for grain transportation (the total amount of subsidies is more than 3 billion rubles);

- preferential leasing (advance payment - 20\%, interest rate $-3.5 \%$, lease term-up to 7 years, the minimum amount of financing for the lessee - from 400,000 rubles, the frequency of payments - monthly, warranty - is not required);

- preferential loans (interest rate $-5 \%$ ); 
- single regional subsidy is aimed at helping to achieve the targets of regional agricultural development programs. The grant agreement sets out the performance targets of the regional program activities for which the grant is requested. The total amount for 2017 was 36 billion rubles, in 2018 - 34,8 billion, in 2019 - 33,9 billion rubles;

- subsidy for reimbursement of part of the interest rate on investment loans taken before January 1, 2017 (the total amount of subsidies in 2019 is 41.6 billion rubles, in 2020 - 35.5 billion rubles, in $2021-28.5$ billion rubles);

- compensation for part of the direct costs incurred for the creation and(or) modernization of agricultural facilities, compensation for part of the cost of transporting agricultural products by land, including rail, transport (for 20204.3 billion rubles were allocated, for $2021-2.97$ billion rubles);

- subsidy for providing green-box support in the field of crop production (allocated 11.3 billion rubles annually);

- subsidy for increasing dairy farming production (the total amount of subsidies planned to be paid annually is 7.96 billion rubles);

- subsidies to manufacturers of agricultural machinery (the amount of subsidies in 2019 is 8 billion rubles, in 2020 and 2021 - 2 billion rubles each).

On April 6, 2019, the rules for granting subsidies to "Rossiyskie Zheleznye Dorogi" JSC (translation - "Russian Railways" JSC) for the transportation of grain by rail from the Krasnoyarsk and Altai administrative territories, Orenburg, Kurgan, Novosibirsk, Omsk, Kemerovo, and Tyumen administrative regions were also approved. The rules apply to transportation from February 1 to August 31 annually.

In Russia, the share of expenditures on agriculture and fishing is just over $1 \%$ in the consolidated budget. For example, in the EU countries - up to $50 \%$ of state support, and now even more funds are directed to support the agricultural sector in connection with the sanctions. Considering the nearest neighbors (and members of the EAEU) - Belarus and Kazakhstan, it should be noted that Belarus allocated $7.6 \%$ of the consolidated budget for state support, while in Kazakhstan $-4.6 \%$. If we compare the Russian Federation and the European Union, Russia allocates 146 rubles per hectare of acreage, and in Europe - 689 euros for all agricultural land. The difference is huge - more than 300 times. It should also be added that in Europe, out of 1 euro invested in agriculture, 52 cents are returned in the form of state subsidies. The situation is similar in the United States (Agricultural.., 2020).

At the expense of the federal budget, 252.1 billion rubles were allocated for the implementation of the state program in 2019. On the one hand, this fact indicates an increase in state support since 2013. On the other hand, this is only a nominal increase, because if we estimate the amount of funding for the program from the beginning of its implementation at comparable prices, it turns out that over seven years, the number of allocated funds has not increased, but on the contrary, has decreased by almost $10 \%$ (Figure 2).

Reimbursement of part of the incurred capex is one of the well-established measures that really affected the development of agriculture. It contributes to the influx of new investors into the industry, as it significantly reduces the payback period of projects and improves the attractiveness of certain areas. Experts note that the reimbursement of part of the capex is the most effective measure of state support. However, a large share of these subsidies goes to market majors. 


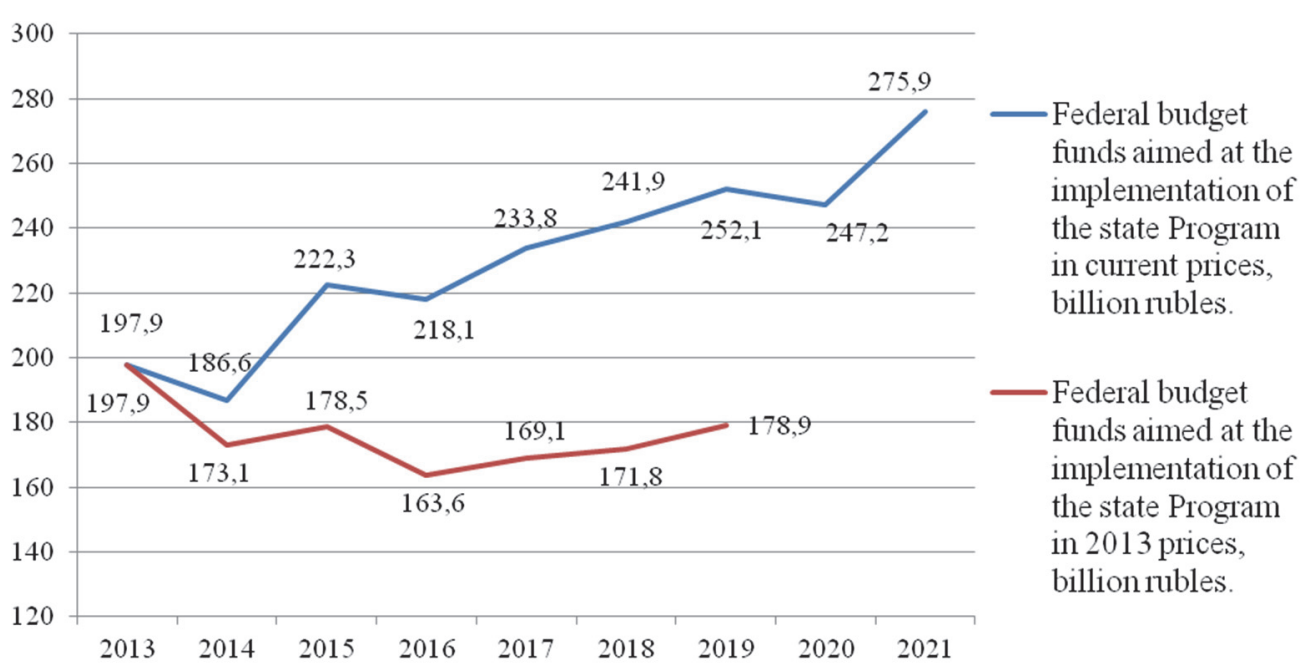

Figure 2. Federal budget funds aimed at implementing the state program

Source: compiled by the author according to the Ministry of Agriculture of the Russian Federation. Retrieved February 25, 2020, from http://mcx.ru/

Preferential financing was not available to everyone in 2017-2018, despite the nominal growth in lending volumes. With low volumes of state support, the subsidy distribution system is highly selective and opaque, which puts companies in unequal conditions. Preferential short-term loans to medium and small enterprises are almost not available. There is a serious imbalance in the territorial distribution and concentration of investments $-62 \%$ of credit limits for two districts (Central and Volga) (Ministry.., 2020), about 70\% of funds for the development of agriculture were also concentrated in the Central Federal District and the Volga Federal District (Ushachev, 2017).

In a greater degree this is the support of banks, because $60 \%$ of the agricultural budget goes to them (Ushachev, 2016), and not directly to producers. A significant part of the funds goes to subsidies at the interest rate of agricultural credits. Several authorized state banks select potential borrowers, after which a contract is concluded with them, under which the borrower is obliged to pay the full loan rate. After six months, a year or two, the state returns some of the money. Often, it does not return, because the agricultural producer with a high loan rate about $15 \%$ - is ruined. The situation is similar in terms of state support for small businesses (Maslova, 2018).

In the case of insurance, the producer of agricultural products covers the insurance costs at his own expense. It receives state subsidies only after a few months, and this process involves the need to provide several justifications. Also, the farmer in the settlement of losses is faced with the fact that the insured amount is inadequate to real losses.

Another reason lies in the established practice of concluding insurance contracts during sowing operations, that is, during the period when the agricultural producer bears the highest seasonal expenses.

It should also be noted that state subsidies only apply to crop insurance. State support does not apply to property insurance which is the producer's durable 
equipment. The same can be said for other risks that require insurance when entering into leasing agreements and obtaining bank loans (Istomina, 2013).

According to the new version of the state program, there was a consolidation of state support measures in 2017, inter-budget transfers were provided in seven main areas. One of the main areas is to promote the achievement of targets in the implementation of regional programs. This is, in fact, a single subsidy, which includes 26 previously paid subsidies.

On the one hand, this kind of subsidy makes it possible to expand the ability of subjects to operate with state support funds, since in recent years almost 5 billion rubles were returned to the state budget and the regions did not have time to use them, or for some reason could not do it. But, on the other hand, in priority areas of development, at least in those where import substitution has not yet been achieved, it is necessary to leave this tool in the hands of the state.

In order to improve state support, it is necessary to achieve a correspondence between the high goals and objectives set for agriculture and the financial resources allocated for this purpose. State support mechanisms should be made transparent and predictable, and they should not change every year. This will create an important and necessary basis for long-term planning for farmers and businesses. About $50 \%$ of all subsidies are allocated each year to support lending to investment activities. Recently, new mechanisms have appeared that stimulate investment activity in the agricultural sector. The first - reimbursement of part of the costs incurred is very popular in the industry. The second is that a preferential lending mechanism has been operating since 2017. But the financial resources allocated to the development of this mechanism are not enough. Only one loan out of five, which was attracted to the industry in 2017, had a component of state support. For small businesses, the percentage of such loans was even lower. In general, the cost of loans for farmers is very high.

As a result, despite the work of the Ministry of Agriculture of the Russian Federation to stimulate investment activity, over the five years of implementation of the state program, the increase in fixed capital expenditure of the industry amounted to only $1.6 \%$. Such growth rates are not sufficient to solve the problems facing the industry, including to a greater extent in connection with the declared import substitution.

Today, not only issues related to the need to increase the amount of state support are becoming relevant, but also the effective use of budget funds allocated to support agriculture in the regions of the Russian Federation (Bukshpan et al., 2018).

In addition to the fall in real incomes for the sixth consecutive year (according to official statistics, the standard of living has fallen by $11.5 \%$ ), the decline in demand for agricultural products is compounded by an increase in production costs and, as a result, an increase in the price to consumer (Table 2). If the population has high incomes, and the municipalities have tax revenues, rural areas will be able to develop themselves, without relying only on state subsidies (Uzun, 2019).

Analysis of the main directions of the state program measures shows that most of the existing state support measures stimulate the growth of production and export volumes. Compared to 2018, export support has increased significantly from 1.3 to 38.8 billion rubles. However, stabilization mechanisms aimed at im- 
proving the stability of the industry are not enough. This was fully demonstrated in 2017, when, despite very high yields, profitability in the industry significantly decreased.

Table 2

Index of prices

\begin{tabular}{lcccccc}
\hline \multicolumn{1}{c}{ Indicators } & $\mathbf{2 0 1 3}$ & $\mathbf{2 0 1 4}$ & $\mathbf{2 0 1 5}$ & $\mathbf{2 0 1 6}$ & $\mathbf{2 0 1 7}$ & $\mathbf{2 0 1 8}$ \\
\hline Agricultural producer price index & 107,8 & 107,9 & 113,5 & 103,8 & 97,7 & 112,9 \\
Producer price index for industrial goods & 103,4 & 106,1 & 112,4 & 104,0 & 107,6 & 111,7 \\
Producer price index in the food industry & 106,1 & 108,4 & 119,4 & 106,6 & 98,3 & 107,6 \\
Consumer price index & 106,8 & 107,8 & 115,5 & 107,1 & 103,7 & 104,3 \\
Consumer price index for food products & 106,2 & 109,7 & 120,2 & 105,8 & 102,8 & 104,7 \\
\hline
\end{tabular}

Source: Federal State Statistic Service. Retrieved from www.gks.ru

Table 3

Actual expenditures on the implementation of measures to improve the housing conditions of rural population under the federal target program "Sustainable development of rural territories" (billion rubles)

\begin{tabular}{cccc}
\hline Years & Consolidated budget & Extra-budgetary funds & Extra-budgetary funds, \% \\
\hline 2014 & 13 & 10 & 43 \\
2015 & 8 & 7 & 47 \\
2016 & 8 & 6 & 43 \\
Total 2014-2016 & 29 & 23 & 44 \\
\hline
\end{tabular}

Source: (Maslova, 2018).

Bipolarity and differentiation of economic entities are not taken into account by the developers of the state program and state support measures. What is good for a large commodity business is not suitable for small businesses (Table 3). A striking example is the situation with preferential loans. Since 2017, a quota of $20 \%$ has been allocated for small businesses. But this limit is not selected. This is largely due to the fact that when assessing credit risk, banks usually evaluate loans issued to small businesses as a low-quality category (Maslova, 2018).

The state agrarian policy is an integral part of the state socio-economic policy aimed at sustainable development of agriculture and rural territories. According to the federal law, sustainable development of rural territories means their stable socio-economic development, increasing agricultural production, increasing agricultural efficiency, achieving full employment of the rural population and improving their standard of living, and rational use of land.

State support for the development of agricultural territories is estimated at 7 billion rubles, while the allocated funds from both the consolidated budget and extra-budgetary sources for the implementation of measures to improve the housing conditions of the rural population under the federal target program "Sustainable Development of Rural Territories" have only decreased since 2014. 
Departmental target program "Sustainable Development of Rural Areas" was developed by June 2019 to replace federal target program, according to which the total amount of financing for 2019-2025 is 204.4 billion rubles. Every year, from 17 to 22 billion rubles will be allocated from the federal budget for this program, 4-6 billion rubles from the budgets of the constituent entities of the Russian Federation, and 3-4 billion rubles from extra-budgetary sources.

The main and primary task is to encourage Russian manufacturers and entrepreneurs to switch their enterprises to innovative ways. Direct state support for production is provided in various forms, with the focus on the need to develop innovative activities. But it is more necessary for the state to create conditions for free competition that encourage enterprises to technical and technological upgrade their production. Antitrust levers are an example of radical measures, but despite their importance, these tools are not enough to create a competitive market environment in the Russian Federation. Lack of competition directly negatively affects the dynamics of labor productivity. This leads to the non-competitiveness of domestic enterprises, which is manifested not only in the world, but also in the domestic market.

Recently, fair criticism of large companies, state corporations and agricultural holdings has increased in the Russian Federation. Very often, they are artificially protected from market competition, property is transferred to them without bidding. Some companies were moving away from financial control. Therefore, a competitive market environment cannot be created in Russia, at least not yet.

It cannot be created without a radical change in the existing practice of lobbying by officials of all ranks for the interests of individual companies, mainly large ones. But in the Russian Federation, unfortunately, much less attention is paid to this than is necessary (Primakov, 2011). A serious fight against corruption in agriculture is also impossible without breaking the link between government officials and agribusiness.

\section{Conclusion}

Features of agriculture do not allow the full development of the agro-industrial complex within the framework of a market economy, so an active role of the state in the functioning of economic processes is necessary. Maintaining a balance of interests and leveling the contradictions of all structures in agricultural production and the product market is also unthinkable without a responsible manager, that is, the government, the state.

However, the state support program currently being implemented is mainly declarative in nature, with targeted support for certain sub-sectors. The program in terms of its production parameters and financial support, as well as previously adopted documents, is not aimed at the necessary innovative development path with the solution of the entire complex of tasks of ensuring food security.

In recent years the largest amount of agricultural financing is accounted for by the following areas: support for banks (up to $60 \%$ of the agricultural budget) and subsidies to the regions of the Russian Federation to achieve targets in the implementation of regional programs. The most popular business tool is compensation of interest rate, and about $50 \%$ of subsidies are for concessional lending to invest- 
ment activities (reimbursement of part of the costs incurred, a preferential loan mechanism). Subsidies to the regions are primarily aimed at achieving indicators of import substitution, production growth and export volumes.

A significant deterrent to the expansion of investment activity is the decline in demand of the population, associated with the continuing decline in real incomes for the sixth years. This is one of the main problems, and not only for the development of agriculture, but also for other industrial sectors.

More than $85 \%$ of the funds allocated by the state for the development of agriculture are received by large companies, which seriously hampers the development of small and medium-sized businesses in the agricultural sector. About 50\% of agricultural companies do not receive state support at all or receive it in the amount of up to 1 million rubles. A quota of $20 \%$ is allocated annually for small businesses, but this limit is not chosen because banks assess credit risks to small businesses as too high and the loan interest subsidy scheme when compensation occurs through six months to a year after interest payments, leads to the ruin of individual private farmers. Agricultural holdings have huge money and other assets in their accounts, which gives them the opportunity to receive preferential loans under collateral.

On the one hand, the state agrarian policy is aimed at sustainable development of agriculture and rural territories. On the other hand, in practice in Russia there is an obvious trend towards monopolization in agriculture.

The current practice of state support of agriculture in Russia contributes to the formation of an abnormal structure of agriculture, artificially protects large companies, agricultural holdings and companies with state participation, from market competition.

\section{References}

Bukshpan, A.A., Gusak, T.S., \& Serdyuk, O.S. (2018). State support of agrarian and industrial complex in the Russian Federation in transitive economy. Ekonomika i biznes: teoriya i praktika [Economy and business: theory and practice], (9), 31-35. (In Russ.) doi: 10.24411/2411-0450-2018-10006.

Burmistrova, A.A., Rodionova, N.K., \& Kondrashova, I.S. (2014). Gosudarstvennaya podderzhka sel'skogo khozyaistva vazhneishii faktor razvitiya APK Rossii [The state support of agriculture - the major factor of development of agrarian and industrial complex of Russia]. Sotsial'no-ekonomicheskie yavleniya i protsessy [Social-Economic Phenomena and Processes], 9(3), 14-16. (In Russ.)

Federal Law dated 29.12.2006 (ed. 25.12.2018) No. 264-FZ "On Agricultural Development". (In Russ.) Retrieved April 19, 2020, from http://www.consultant.ru/cons/cgi/online. cgi?from=286510-0\&rnd=B88CFD8D0C70C944E569E73C0BF6187A\&req=doc\&base= LAW $\& n=314385 \&$ REFDOC $=286510 \&$ REFBASE $=$ LAW\#9kjkx 80 tmo

Federal State Statistic Service. Retrieved from www.gks.ru (In Russ.)

Information guide on measures and directions of state support of the agroindustrial complex of the Russian Federation. Retrieved February 25, 2020, from http://www.gp.specagro.ru (In Russ.)

Istomina, L.A. (2013). Analiz gosudarstvennoi podderzhki APK [Analysis of state support for agriculture]. Bulletin of Udmurt University. Series Economics and Law, (2), 47-51. (In Russ.)

Kamilov, M.K., \& Kamilova, P.D. (2012). Gosudarstvennoe regulirovanie i podderzhka APK Rossii posle vstupleniya v VTO [Government regulation and support of Russia agriculture after WTO]. Regional'nye problemy preobrazovaniya ekonomiki [Regional problems of transforming the economy], (2), 181-187. (In Russ.) 
Karavdin, A.A. (2016). To a question of government regulation of agro-industrial sector of the economy. Conference Papers of the VIII International scientific and practical conference "Innovation in Agriculture" (Moscow, April, 20-22, 2016) (pp. 146-149). Moscow, RUDN University. (In Russ.)

Maslova, V.V. (2018). Sovershenstvovanie ekonomicheskogo mekhanizma v agrarnom sektore ekonomiki [Improvement of the economic mechanism in the agricultural sector]. $B u$ dushchee sel'skikh territorii Rossii v kontekste razvitiya agrarnogo mira (MEF-2018) [The Future of rural areas of Russia in the context of the agricultural world (MEF-2018)] (pp. 65-72). Moscow. (In Russ.)

Ministry of Agriculture of the Russian Federation. Retrieved from http://mcx.ru/ (In Russ.)

OECD. (2020). Agricultural support. Retrieved February 25, 2020, from https://data.oecd.org/ agrpolicy/agricultural-support.htm

Primakov, E.M. (2011). Mysli vslukh [Thinking out loud]. Rossiyskaya Gazeta, 135(5511). (In Russ.)

Privalova, S.G. (2009). Teoreticheskie aspekty gosudarstvennoi podderzhki APK [Theoretical aspects of state support of agriculture]. Agrarnyi vestnik Urala [Agrarian Bulletin of the Urals], (12), 20-25. (In Russ.)

Shagaida, N.I., \& Uzun, V.Ya. (2017). Tendentsii razvitiya $i$ osnovnye vyzovy agrarnogo sektora Rossii. Analiticheskii doklad RANKhiGS [Development trends and main challenges of the Russian agricultural sector. Analytical report of RANEPA]. Moscow, Tsentr strategicheskikh razrabotok Publ. Retrieved May 25, 2020, from https://www.csr.ru/ wp-content/uploads/2017/11/Doklad_selskoe_hozyai-stvo_veb.pdf (In Russ.)

Shutkov, A.A., \& Shutkov, S.A. (2016). Resursno-innovatsionnaya strategiya importozameshcheniya: problemy formirovaniya i realizatsii [Resource-innovative strategy of import substitution: problems of formation and implementation]. Ekonomika sel'skogo khozyaistva Rossii [Russian agriculture economics], (1), 11-19. (In Russ.)

Ushachev, I.G. (2016). Nauchnye problemy importozameshcheniya i formirovaniya eksportnogo potentsiala produktsii agropromyshlennogo kompleksa Rossii [Scientific problems of import substitution and formation of export potential of agricultural products of Russia]. APK: ekonomika, upravlenie [Economics and management of agriculture], (1), 4-22. (In Russ.)

Ushachev, I.G. (2017). Sovremennye tendentsii i vzglyad v budushchee razvitiya APK Rossii [Modern trends and a look into the future of the development of the AIC of Russia]. Prikladnye ekonomicheskie issledovaniya [Applied economic research], (2), 4-7. (In Russ.)

Uzun, V.Ya. (2019). Gosprogramma kompleksnogo razvitiya sel"skikh territorii: analiz proekta [State Program of Integrated Development of Rural Territories: Project Analysis]. Ekonomicheskoe razvitie Rossii [Economic development of Russia], 26(5), 30-34. (In Russ.)

Article history:

Received: 25 March 2020

Revised: 23 May 2020

Accepted: 31 May 2020

\section{For citation:}

Karavdin, A.A. (2020). Justification of necessity and analysis of state support of agro-industrial complex in the Russian Federation. RUDN Journal of Economics, 28(3), 585-596. http:// dx.doi.org/10.22363/2313-2329-2020-28-3-585-596

\section{Bio note:}

Andrey A. Karavdin, postgraduate student of the Department of International Economic Relations of Faculty of Economics of Peoples Friendship University of Russia (RUDN University). eLIBRARY SPIN-code: 7720-4071, ORCID iD: https://orcid.org/0000-00020501-7050. E-mail: aka.kurgan@mail.ru 


\title{
Обоснование необходимости и анализ государственной поддержки агропромышленного комплекса в Российской Федерации
}

\author{
А.А. Каравдин \\ Российский университет дружбы народов \\ Российская Федерация, 117198, Москва, ул. Миклухо-Маклая, 6
}

\begin{abstract}
Аннотация. Вопросы, касающиеся государственной поддержки агропромышленного комплекса (АПК), являются актуальными для всех без исключения стран мира, в том числе и для Российской Федерации. В статье рассматриваются ключевые проблемы АПК, порождаемые в большей степени особенностями сельского хозяйства. Обосновывается необходимость государственной поддержки агропромышленного комплекса России на основе выделенных проблем. Анализируются направления и меры государственной поддержки в России, расхождения между заявленными в государственной программе развития агропромышленного комплекса целями и практическими результатами. Отсутствие комплексного подхода к решению имеющихся задач и должного контроля за выполнением госпрограммы, непродуманное и недостаточное финансирование отдельных программ, лоббирование крупными агрохолдингами своих интересов и монополизация сельскохозяйственного производства не позволяют рассчитывать на развитие малого агробизнеса и сельских территорий.
\end{abstract}

Ключевые слова: агропромышленный комплекс, государственная поддержка, аграрная политика, государственная программа, субсидии

\section{История статьи:}

Дата поступления в редакцию: 25 марта 2020 г.

Дата проверки: 23 мая 2020 г.

Дата принятия к печати: 31 мая 2020 г.

\section{Для цитирования:}

Karavdin A.A. Justification of necessity and analysis of state support of agro-industrial complex in the Russian Federation // Вестник Российского университета дружбы народов. Серия: Экономика. 2020. Т. 28. № 3. C. 585-596. http://dx.doi.org/10.22363/2313-2329-202028-3-585-596

\section{Сведения об авторе:}

Каравдин Андрей Андреевич, аспирант кафедры международных экономических отношений экономического факультета Российского университета дружбы народов. eLIBRARY SPIN-код: 7720-4071, ORCID iD: https://orcid.org/0000-0002-0501-7050. E-mail: aka.kurgan@mail.ru 